\title{
1. Discrimination against women: doctrine, practice, and the path forward
}

\section{INTRODUCTION: DISCRIMINATION AGAINST WOMEN THROUGH THE LENS OF INTERNATIONAL HUMAN RIGHTS LAW}

The international human rights law regime, as we understand it today, was established post World War II. This global conflict resulted in the loss of millions of lives and the total destruction of entire countries and cities. Foremost, the Holocaust took place at the hands of Nazi Germany and their collaborators, leading to the execution of about six million Jews. ${ }^{1}$ International human rights law was adopted after World War II to restore and build new societies based on human dignity, rule of law, and peace. After World War II, the United Nations was created in 1945, through the adoption of the United Nations Charter, ${ }^{2}$ to advance international peace and security and to promote economic and social progress for all peoples.

A key instrument in the development of international human rights law was the Universal Declaration of Human Rights, adopted in $1948 .^{3}$ The Universal Declaration of Human Rights, now considered a source of customary international law, recognized for the first time many of the civil, political, economic, social, and cultural rights that permeate most international treaties today. The Universal Declaration includes paramount rights to life, to be free from slavery and torture, to an effective remedy, to work, and to an education, among others. Acknowledging the need for binding documents, the international community adopted the International Covenants on Civil and Political Rights (hereinafter "ICCPR") 4 and Economic, Social and Cultural Rights (hereinafter "ICESCR") 5 in 1966 codifying for the first time the rights contained in the Universal Declaration.

\footnotetext{
1 For more reading, see United States Holocaust Memorial Museum, Introduction to the Holocaust, https://encyclopedia.ushmm.org/content/en/article/introduction-to-the-holocaust (last visited on May 19, 2021).

2 See generally U.N. Charter, June 26, 1945, 59 Stat. 1031, T.S. 993, 3 Bevans 1153, entered into force Oct. 24, 1945.

3 See generally Universal Declaration of Human Rights, G.A. Res. 217A (III), U.N. Doc. A/810 at 71 (1948).

4 See generally International Covenant on Civil and Political Rights, G.A. Res. 2200A (XXI), 21 U.N. GAOR Supp. (No. 16) at 52, U.N. Doc. A/6316 (1966), 999 U.N.T.S. 171, entered into force Mar. 23, 1976.

5 See generally International Covenant on Economic, Social and Cultural Rights, G.A. Res. 2200A (XXI), 21 U.N. GAOR Supp. (No. 16) at 49, U.N. Doc. A/6316 (1966), 993 U.N.T.S. 3, entered into force Jan. 3, 1976.
} 
The human rights system was created to restrain the activity and power of states towards the individual. It was the result of wars driven by totalitarian states in which many abuses against people had been committed. The system first greatly emphasized civil and political rights as a key to safeguarding the human person, peace, and security. The Soviet Bloc in particular highlighted the equal importance of economic, social, and cultural rights and the need to subject compliance of these rights to the availability of state resources.

References to the rights of women appear early in international human rights law instruments. The United Nations Charter refers in its Preamble to the equal rights of men and women. The Universal Declaration of Human Rights recognizes in Articles 1 and 7 the principle of equality, and in Article 2 it prohibits distinctions on the basis of sex. Both the ICCPR and the ICESCR prohibit discrimination on the basis of sex in Article 2 and advance the equality of men and women in Article $3 .^{6}$

These instruments, however, proved insufficient to improve the situation of women and to advance the respect and protection of their human rights. In parallel with the development of the international human rights law system, the work of the women's rights movement and the Commission on the Status of Women were key to bring visibility to the need for a specialized treaty that exclusively addressed the realities faced by women. The Commission on the Status of Women was established in 1946 as part of the United Nations to adopt strategies and recommendations which could advance the equality of women. The Commission actively propelled the adoption of a number of treaties and instruments by the United Nations General Assembly, including the Convention on the Political Rights of Women (1953), the Convention on the Nationality of Married Women (1957), the Convention on Consent to Marriage, Minimum Age for Marriage, and Registration of Marriages (1962), and the Declaration on the Elimination of Discrimination against Women (1967). These were all precursor instruments to the eventual adoption of the Convention on the Elimination of all Forms of Discrimination against Women, covering different dimensions of the human rights of women.

All these efforts raised the awareness of the international community of the need to adopt a more multifaceted and comprehensive instrument related to the rights of women. This led to the drafting of the Convention on the Elimination of all Forms of Discrimination against Women (hereinafter "CEDAW") ${ }^{7}$ by the Commission on the Status of Women and its eventual adoption in 1979. The adoption of CEDAW was joined by the establishment of its monitoring committee as disposed in Article 17. Civil society organizations were crucial in the growing visibility of women's rights issues among decision-makers in the international community and the eventual text of the treaty. CEDAW - which will be discussed in detail in this section - is centered on the issue of discrimination against women and its many layers and intricacies. CEDAW is a watershed moment in the history of the human rights of women, recognizing

6 The ICCPR also provides in Article 26 that

All persons are equal before the law and are entitled without any discrimination to the equal protection of the law. In this respect, the law shall prohibit any discrimination and guarantee to all persons equal and effective protection against discrimination on any ground such as race, colour, sex, language, religion, political or other opinion, national or social origin, property, birth or other status.

7 See generally Convention on the Elimination of All Forms of Discrimination against Women, G.A. Res. 34/180, 34 U.N. GAOR Supp. (No. 46) at 193, U.N. Doc. A/34/46, entered into force Sept. 3, 1981. 
state responsibility to prevent and respond to discrimination against women, both in the family and in all spheres of public life.

The right of women to be free from all forms of discrimination is still a pillar of their human rights and a basic principle and state obligation. The CEDAW, and its goals to advance women's equality and non-discrimination, were cross-cutting themes in the adoption of the Beijing Declaration and Platform of Action. ${ }^{8}$ The Beijing Declaration and Platform of Action was the product of the Fourth World Conference on Women held in September of 1995, including approximately 17,000 participants and 30,000 activists. ${ }^{9}$ The resulting document is historic in calling for the empowerment and equal participation of women in all social dimensions. ${ }^{10}$ The document also underscored women's human rights as human rights. ${ }^{11}$

Most of the international law treaties today advancing human rights contain a prohibition of all forms of discrimination on the basis of sex. There has also been a growing awareness of the magnitude and prevalence of the issue of gender-based violence and its connection to discrimination against women. This connection was established by the CEDAW Committee in its famous General Recommendation 19, establishing that gender-based violence is a form of discrimination under Article 1 of CEDAW. Understanding the dynamics and state obligations to address discrimination and gender-based violence against women is key to grasping the nuance of human rights issues concerning women. Therefore, this chapter provides an overview of the basic principles related to discrimination and gender-based violence. These principles will be later explained in detail in future chapters in connection with issues affecting women in modern times.

\section{CEDAW AND DISCRIMINATION AGAINST WOMEN}

The leading treaty in the world on discrimination against women is the Convention on the Elimination of all Forms of Discrimination against Women (hereinafter "CEDAW"). It prohibits discrimination in the areas of political and public life, nationality, education, employment, health, economic and social benefits, and marriage and family life. It addresses both direct and indirect discrimination, in the public and private spheres, in the areas of civil, political, economic, social, and cultural rights. CEDAW also mandates states to refrain from any acts of discrimination against women, and amend their current laws to prevent and respond to this problem. CEDAW moreover establishes an important connection between all rights of women and its overall prohibition of discrimination. As part of an integral strategy to address discrimination against women, state parties must adopt measures to eradicate stereotypical

8 See generally Beijing Declaration and Platform of Action, September 15, 1995, www.un.org/en/ events/pastevents/pdfs/beijing_declaration_and_platform_for_action.pdf (last visited on September 24, 2021) (hereinafter "Beijing Declaration and Platform of Action").

9 For more information on the Fourth World Conference on Women and the legacy of the Beijing Platform of Action, see UN Women, The Beijing Platform for Action Turns 20, https://beijing20 .unwomen.org/en/about (last visited on May 19, 2021).

10 See Beijing Platform of Action, supra note 8, pp. 18-108 (in which you can find a discussion of strategic objectives and needed state actions to achieve the equality of women, based on the critical areas of concern identified, including poverty, education, health, violence, armed conflict, economy, power and decision-making, institutional mechanisms, human rights, media, the environment, and the girl-child).

11 See Beijing Declaration, supra note 8, ๆ 14. 
and cultural patterns of behavior that work to the detriment of women, and temporary special measures to address past discrimination. Excerpts from the Preamble and the main Articles of CEDAW have been included below.

\section{A Convention on the Elimination of all Forms of Discrimination against Women (CEDAW)}

U.N. Doc. A/34/46, entered into force Sept. 3, 1981

\section{The States Parties to the present Convention,}

Noting that the Charter of the United Nations reaffirms faith in fundamental human rights, in the dignity and worth of the human person and in the equal rights of men and women,

Noting that the Universal Declaration of Human Rights affirms the principle of the inadmissibility of discrimination and proclaims that all human beings are born free and equal in dignity and rights and that everyone is entitled to all the rights and freedoms set forth therein, without distinction of any kind, including distinction based on sex, $\cdots$

Recalling that discrimination against women violates the principles of equality of rights and respect for human dignity, is an obstacle to the participation of women, on equal terms with men, in the political, social, economic and cultural life of their countries, hampers the growth of the prosperity of society and the family and makes more difficult the full development of the potentialities of women in the service of their countries and of humanity,

Bearing in mind the great contribution of women to the welfare of the family and to the development of society, so far not fully recognized, the social significance of maternity and the role of both parents in the family and in the upbringing of children, and aware that the role of women in procreation should not be a basis for discrimination but that the upbringing of children requires a sharing of responsibility between men and women and society as a whole,

Aware that a change in the traditional role of men as well as the role of women in society and in the family is needed to achieve full equality between men and women,

Determined to implement the principles set forth in the Declaration on the Elimination of Discrimination against Women and, for that purpose, to adopt the measures required for the elimination of such discrimination in all its forms and manifestations, Have agreed on the following:

\section{PART I}

\section{Article I}

For the purposes of the present Convention, the term "discrimination against women" shall mean any distinction, exclusion or restriction made on the basis of sex which has the effect or purpose of impairing or nullifying the recognition, enjoyment or exercise by women, irrespective of their marital status, on a basis of equality of men and women, of human rights and fundamental freedoms in the political, economic, social, cultural, civil or any other field. 


\section{Article 2}

States Parties condemn discrimination against women in all its forms, agree to pursue by all appropriate means and without delay a policy of eliminating discrimination against women and, to this end, undertake:

(a) To embody the principle of the equality of men and women in their national constitutions or other appropriate legislation if not yet incorporated therein and to ensure, through law and other appropriate means, the practical realization of this principle;

(b) To adopt appropriate legislative and other measures, including sanctions where appropriate, prohibiting all discrimination against women;

(c) To establish legal protection of the rights of women on an equal basis with men and to ensure through competent national tribunals and other public institutions the effective protection of women against any act of discrimination;

(d) To refrain from engaging in any act or practice of discrimination against women and to ensure that public authorities and institutions shall act in conformity with this obligation;

(e) To take all appropriate measures to eliminate discrimination against women by any person, organization or enterprise;

(f) To take all appropriate measures, including legislation, to modify or abolish existing laws, regulations, customs and practices which constitute discrimination against women;

(g) To repeal all national penal provisions which constitute discrimination against women.

\section{Article 3}

States Parties shall take in all fields, in particular in the political, social, economic and cultural fields, all appropriate measures, including legislation, to ensure the full development and advancement of women, for the purpose of guaranteeing them the exercise and enjoyment of human rights and fundamental freedoms on a basis of equality with men.

\section{Article 4}

1. Adoption by States Parties of temporary special measures aimed at accelerating de facto equality between men and women shall not be considered discrimination as defined in the present Convention, but shall in no way entail as a consequence the maintenance of unequal or separate standards; these measures shall be discontinued when the objectives of equality of opportunity and treatment have been achieved.

2. Adoption by States Parties of special measures, including those measures contained in the present Convention, aimed at protecting maternity shall not be considered discriminatory.

\section{Article 5}

States Parties shall take all appropriate measures:

(a) To modify the social and cultural patterns of conduct of men and women, with a view to achieving the elimination of prejudices and customary and all other practices which are based on the idea of the inferiority or the superiority of either of the sexes or on stereotyped roles for men and women;

(b) To ensure that family education includes a proper understanding of maternity as a social function and the recognition of the common responsibility of men and women in the 
upbringing and development of their children, it being understood that the interest of the children is the primordial consideration in all cases.

\section{Article 6}

States Parties shall take all appropriate measures, including legislation, to suppress all forms of traffic in women and exploitation of prostitution of women.

\section{PART II}

\section{Article 7}

States Parties shall take all appropriate measures to eliminate discrimination against women in the political and public life of the country and, in particular, shall ensure to women, on equal terms with men, the right:

(a) To vote in all elections and public referenda and to be eligible for election to all publicly elected bodies;

(b) To participate in the formulation of government policy and the implementation thereof and to hold public office and perform all public functions at all levels of government;

(c) To participate in non-governmental organizations and associations concerned with the public and political life of the country.

\section{Article 8}

States Parties shall take all appropriate measures to ensure to women, on equal terms with men and without any discrimination, the opportunity to represent their Governments at the international level and to participate in the work of international organizations.

\section{Article 9}

1. States Parties shall grant women equal rights with men to acquire, change or retain their nationality. They shall ensure in particular that neither marriage to an alien nor change of nationality by the husband during marriage shall automatically change the nationality of the wife, render her stateless or force upon her the nationality of the husband.

2. States Parties shall grant women equal rights with men with respect to the nationality of their children.

\section{PART III}

\section{Article 10}

States Parties shall take all appropriate measures to eliminate discrimination against women in order to ensure to them equal rights with men in the field of education and in particular to ensure, on a basis of equality of men and women:

(a) The same conditions for career and vocational guidance, for access to studies and for the achievement of diplomas in educational establishments of all categories in rural as well as in urban areas; this equality shall be ensured in pre-school, general, technical, professional and higher technical education, as well as in all types of vocational training;

(b) Access to the same curricula, the same examinations, teaching staff with qualifications of the same standard and school premises and equipment of the same quality; 
(c) The elimination of any stereotyped concept of the roles of men and women at all levels and in all forms of education by encouraging coeducation and other types of education which will help to achieve this aim and, in particular, by the revision of textbooks and school programmes and the adaptation of teaching methods;

(d) The same opportunities to benefit from scholarships and other study grants;

(e) The same opportunities for access to programmes of continuing education, including adult and functional literacy programmes, particularly those aimed at reducing, at the earliest possible time, any gap in education existing between men and women;

(f) The reduction of female student drop-out rates and the organization of programmes for girls and women who have left school prematurely;

(g) The same opportunities to participate actively in sports and physical education;

(h) Access to specific educational information to help to ensure the health and well-being of families, including information and advice on family planning.

\section{Article 11}

1. States Parties shall take all appropriate measures to eliminate discrimination against women in the field of employment in order to ensure, on a basis of equality of men and women, the same rights, in particular:

(a) The right to work as an inalienable right of all human beings;

(b) The right to the same employment opportunities, including the application of the same criteria for selection in matters of employment;

(c) The right to free choice of profession and employment, the right to promotion, job security and all benefits and conditions of service and the right to receive vocational training and retraining, including apprenticeships, advanced vocational training and recurrent training;

(d) The right to equal remuneration, including benefits, and to equal treatment in respect of work of equal value, as well as equality of treatment in the evaluation of the quality of work;

(e) The right to social security, particularly in cases of retirement, unemployment, sickness, invalidity and old age and other incapacity to work, as well as the right to paid leave;

(f) The right to protection of health and to safety in working conditions, including the safeguarding of the function of reproduction.

2. In order to prevent discrimination against women on the grounds of marriage or maternity and to ensure their effective right to work, States Parties shall take appropriate measures:

(a) To prohibit, subject to the imposition of sanctions, dismissal on the grounds of pregnancy or of maternity leave and discrimination in dismissals on the basis of marital status;

(b) To introduce maternity leave with pay or with comparable social benefits without loss of former employment, seniority or social allowances;

(c) To encourage the provision of the necessary supporting social services to enable parents to combine family obligations with work responsibilities and participation in public life, in particular through promoting the establishment and development of a network of child-care facilities; 
(d) To provide special protection to women during pregnancy in types of work proved to be harmful to them.

3. Protective legislation relating to matters covered in this article shall be reviewed periodically in the light of scientific and technological knowledge and shall be revised, repealed or extended as necessary.

\section{Article 12}

1. States Parties shall take all appropriate measures to eliminate discrimination against women in the field of health care in order to ensure, on a basis of equality of men and women, access to health care services, including those related to family planning.

2. Notwithstanding the provisions of paragraph 1 of this article, States Parties shall ensure to women appropriate services in connection with pregnancy, confinement and the post-natal period, granting free services where necessary, as well as adequate nutrition during pregnancy and lactation.

\section{Article 13}

States Parties shall take all appropriate measures to eliminate discrimination against women in other areas of economic and social life in order to ensure, on a basis of equality of men and women, the same rights, in particular:

(a) The right to family benefits;

(b) The right to bank loans, mortgages and other forms of financial credit;

(c) The right to participate in recreational activities, sports and all aspects of cultural life.

\section{Article 14}

1. States Parties shall take into account the particular problems faced by rural women and the significant roles which rural women play in the economic survival of their families, including their work in the non-monetized sectors of the economy, and shall take all appropriate measures to ensure the application of the provisions of the present Convention to women in rural areas. ...

\section{PART IV}

Article 15

1. States Parties shall accord to women equality with men before the law.

2. States Parties shall accord to women, in civil matters, a legal capacity identical to that of men and the same opportunities to exercise that capacity. In particular, they shall give women equal rights to conclude contracts and to administer property and shall treat them equally in all stages of procedure in courts and tribunals.

3. States Parties agree that all contracts and all other private instruments of any kind with a legal effect which is directed at restricting the legal capacity of women shall be deemed null and void.

4. States Parties shall accord to men and women the same rights with regard to the law relating to the movement of persons and the freedom to choose their residence and domicile. 


\section{Article 16}

1. States Parties shall take all appropriate measures to eliminate discrimination against women in all matters relating to marriage and family relations and in particular shall ensure, on a basis of equality of men and women:

(a) The same right to enter into marriage;

(b) The same right freely to choose a spouse and to enter into marriage only with their free and full consent;

(c) The same rights and responsibilities during marriage and at its dissolution;

(d) The same rights and responsibilities as parents, irrespective of their marital status, in matters relating to their children; in all cases the interests of the children shall be paramount;

(e) The same rights to decide freely and responsibly on the number and spacing of their children and to have access to the information, education and means to enable them to exercise these rights;

(f) The same rights and responsibilities with regard to guardianship, wardship, trusteeship and adoption of children, or similar institutions where these concepts exist in national legislation; in all cases the interests of the children shall be paramount;

(g) The same personal rights as husband and wife, including the right to choose a family name, a profession and an occupation;

(h) The same rights for both spouses in respect of the ownership, acquisition, management, administration, enjoyment and disposition of property, whether free of charge or for a valuable consideration.

2. The betrothal and the marriage of a child shall have no legal effect, and all necessary action, including legislation, shall be taken to specify a minimum age for marriage and to make the registration of marriages in an official registry compulsory. ...

\section{B Reflections and Questions}

1. There are many principles reflected in Article 1(1) of CEDAW and its definition of discrimination. CEDAW prohibits all distinctions, exclusions, and restrictions based on sex. This includes both direct and indirect discrimination in the political, economic, social, cultural, and civil spheres. The CEDAW Committee in its General Recommendation 28 has referred to direct discrimination as different treatment explicitly founded on sex and gender differences. Indirect discrimination instead alludes to laws, policies, programs, and practices that appear neutral, but have a discriminatory effect on women because of pre-existing inequalities. ${ }^{12}$ What is the difference between distinctions, exclusions, and restrictions? How can it be determined that a law, policy, or practice, which appears neutral, has a disproportionate or negative impact on women?

12 See General Recommendation No. 28 on the Core Obligations of States Parties under Article 2 of the Convention on the Elimination of All Forms of Discrimination against Women, Committee on the Elimination of Discrimination against Women, 47th Sess., U.N. Doc. C/2010/47/GC.2, q 16 (Oct. 19, 2010) (hereinafter CEDAW Committee, General Recommendation 28), discussed in section III of this chapter. 
2. What is the difference between sex and gender? The text of CEDAW and its Article 1(1) contain a prohibition of discrimination on the basis of sex. The CEDAW Committee has alluded too in its General Recommendations to both sex and gender motives to discriminate. The term sex usually refers to the biological and physical characteristics and features that distinguish women and men, including their reproductive capacity. ${ }^{13}$ The term gender is broader and refers to the roles and notions that society assigns to women and men based on their sex assigned at birth. ${ }^{14}$ The World Health Organization has referred to five important elements that are comprehended in the concept of gender: relational, hierarchical, historical, contextual, and institutional. ${ }^{15}$ Women and men are raised with norms, behaviors, and expectations of their behavior in their public and private lives based on their sex assigned at birth. Chapter 4 will also discuss how the term gender is now understood to include the social realities and problems faced by lesbian, bisexual, transgender, and intersex women.

3. In the case of women in particular, these gender-socially constructed roles have been used historically to place them at a disadvantage in their families, communities, and countries. ${ }^{16}$ These roles have also impacted how most societies are structured, including legislation, policies, and practices which have treated women unequally and as second-class citizens in comparison with their male counterparts in their access to economic resources, property, credit, employment, education, health care, nationality, and other social benefits. Women's reproductive capacity and their maternity has been used frequently to relegate them to the home, unpaid work, and to limit their incursion in the employment, education, and political settings. Women's role has also been limited in decision-making, economic power structures, and reaching high political office, due to child-rearing responsibilities and unpaid work at home. ${ }^{17}$ These historical factors underlie many of the rights contained in CEDAW.

4. The layout of the CEDAW Convention also refers to a historical concern over legal and practical barriers faced by women to exercise their citizenship rights in an autonomous way globally. Key challenges have included impediments to voting and being elected to public office; to entering into contracts; to securing independent employment and accessing higher education; to partaking in the decision-making within public institutions, employers, and organizations; limits to free expression, association, and access to information to facilitate the exercise of rights; and legal barriers to acquiring, changing, and retaining their nationality. Many of these concerns are reflected in CEDAW and its Articles 2 and 3 (and their heavy emphasis on the need for equal treatment in the laws and by public

13 See World Health Organization, Gender, Equity, and Human Rights: Glossary of Terms and Tools, Definition of Sex, www.who.int/gender-equity-rights/knowledge/glossary/en/ (last visited on May 19, 2021) (hereinafter WHO Gender Glossary of Terms).

${ }_{14}$ See id. The Council of Europe Convention on preventing and combating violence against women and domestic violence also defines gender in its Article 3(c) as follows: "'gender' shall mean the socially constructed roles, behaviours, activities and attributes that a given society considers appropriate for women and men." See Council of Europe Convention on preventing and combating violence against women and domestic violence, Art. 3(c), May 11, 2001, C.E.T.S. No. 210 (hereinafter Istanbul Convention).

15 See WHO Gender Glossary of Terms, supra note 13, Definition of Gender.

16 For a general overview of forms of disadvantage that women and girls have faced historically, see Beijing Platform of Action, supra note 8, ๆ $41-209$.

17 For more discussion, see id., $\mid \uparrow 150-209$. 
authorities and institutions); 7 and 8 (on participation in political and public life and the right to vote); 9 (codifying the equal right of women to acquire, change, and retain their nationality); and 15 (mandating states to accord women identical legal capacity to men in legal and civil matters). In the United States, the adoption of the Nineteenth Amendment ${ }^{18}$ of the Constitution in particular was a key historical moment in recognizing the right to vote for women and raising awareness on the limitations women faced in exercising their citizenship rights. ${ }^{19}$

5. Do you notice anything missing in the text of CEDAW? One of the most important historical omissions of CEDAW has been the problem of gender-based violence. Therefore, the CEDAW Committee has adopted three General Recommendations - 12, 19, and 35 addressing the complexity of this issue and defining state obligations in this area. ${ }^{20}$ General Recommendations 19 and 35 of the CEDAW Committee are discussed in detail in Chapter 2 of this casebook.

6. There are also ongoing discussions at the United Nations level of whether there should be a treaty solely focused on gender-based violence and separate from CEDAW. Do you think there is a need to adopt a new treaty on gender-based violence? What would be the advantages and disadvantages? What should be its main components and features? ${ }^{21}$

7. CEDAW is still the most reserved treaty in the world. This has challenged its adequate and prompt implementation. According to the Vienna Convention on the Law of the Treaties, states may make unilateral statements when ratifying a treaty limiting the legal effect of certain provisions. ${ }^{22}$ Reservations, however, should not be incompatible with the object and purpose of a treaty. Should states be allowed to enter reservations to international treaties? ${ }^{23}$ Should all universal human rights treaties be treated the same when it comes to reservations?

8. One of the most important features of CEDAW is that it delves into the family and prohibits discrimination within this cornerstone social institution. It is one of the first treaties to define a clear set of state obligations to protect members of the family. The treaty breaks convention with traditional international human rights law, piercing the veil of a mostly private and taboo institution in international affairs. Article 16 of CEDAW mandates states

18 See United States Constitution, Nineteenth Amendment, passed by Congress on June 4, 1919 and ratified on August 18, 1920, www.senate.gov/civics/constitution_item/constitution.htm?utm_content= buffer05951\#amdt_19_(1920) (last visited on May 19, 2021).

19 For a detailed overview of historical challenges faced by women in the exercise of their citizenship rights in the United States and the impact of the passage of the Nineteenth Amendment, see Felice Batlan, "She Was Surprised and Furious": Expatriation, Suffrage, Immigration, and the Fragility of Women's Citizenship, 1907-1940, 15 Stan. J. C.R. \& C.L. 315, 315-328 (2020).

${ }_{20}$ See CEDAW Committee, General Recommendations 12, 19, and 35 on gender-based violence, www.ohchr.org/en/hrbodies/cedaw/pages/recommendations.aspx (last visited on May 19, 2021).

${ }_{21}$ For arguments in favor of a new global treaty on gender-based violence see Report of the Special Rapporteur on violence against women, its causes and consequences, U.N. Doc. A/HRC/29/27' ฯฯ 6-65 (June 10, 2015).

22 See Vienna Convention on the Law of Treaties, 1155 U.N.T.S. 331, 8 I.L.M. 679, entered into force Jan. 27, 1980, Arts. 19-22.

23 For more reading, see Linda M. Keller, Impact of States Parties' Reservations to the Convention on the Elimination of All Forms of Discrimination against Women, Мich. ST. L. Rev. 309, 315-326 (2014). 
to take all appropriate measures to eliminate discrimination against women in all matters relating to marriage and family relations, and pursue the advancement of the principle of equality. These matters include decisions concerning entering or dissolving a marriage, inheritance, family name, and the number and spacing of children. Additional important language is provided by the CEDAW Committee General Recommendations 21 and 29 on the economic consequences of marriage, family relations, and its dissolution. ${ }^{24}$ Should an international treaty be interfering with family affairs? Under which circumstances should states intervene to protect a woman from discrimination by her spouse, partner, or other family members?

9. Do all women experience discrimination in the same way? Several factors can combine to accentuate the experience of discrimination women face on the basis of their sex and gender. These may include race, ethnicity, age, economic position, migrant status, disabilities, and being deprived of liberty, among others. The CEDAW Committee has increasingly recognized intersecting forms of discrimination which affect women in a very particular way, and expose them to forms of exclusion, inferior treatment, and gender-based violence. The problem of intersectionality and how it is reflected in treaties and caselaw is discussed in detail in Chapter 3 of this casebook. Intersectionality proposes to understand the realities faced by women with a heterogeneous lens, considering social factors which determine social disadvantage, oppression, and class differences. ${ }^{25}$ Professor Kimberlé Crenshaw first used the term intersectionality to describe the intricacies of race and gender, and how they connect to accentuate the disadvantage of women belonging to racial groups ${ }^{26}$ The CEDAW Committee for its part has defined intersectionality as:

Intersectionality is a basic concept for understanding the scope of the general obligations of States parties contained in article 2 . The discrimination of women based on sex and gender is inextricably linked with other factors that affect women, such as race, ethnicity, religion or belief, health, status, age, class, caste and sexual orientation and gender identity. Discrimination on the basis of sex or gender may affect women belonging to such groups to a different degree or in different ways to men. States parties must legally recognize such intersecting forms of discrimination and their compounded negative impact on the women concerned and prohibit them. They also need to adopt and pursue policies and programmes designed to eliminate such occurrences, including, where appropriate, temporary special measures in accordance with article 4 , paragraph 1 , of the Convention and general recommendation No. $25 .{ }^{27}$

The CEDAW Committee, in its General Recommendation 28, by adopting an intersectional approach, has mandated states to adopt policies considering the intersectional burdens and

24 See CEDAW Committee General Recommendations 21 and 29, www.ohchr.org/EN/HRBodies/ CEDAW/Pages/Recommendations.aspx (last visited on May 19, 2021).

25 For more discussion of the development of the concept of intersectionality and its incorporation in the internationalman rights framework, see LORENA SOSA, INTERSECTIONALITY IN THE HuMAN Rights Legal Framework on Violence against Women; at the Center or the Margins? 7-9 (Cambridge University Press, 2017).

26 See Kimberlé Crenshaw, Demarginalizing the Intersection of Race and Sex: A Black Feminist Critique of Antidiscrimination Doctrine, Feminist Theory and Antiracist Politics, 1989(1) UnIVERSITY of Chicago Legal Forum, Article 8, 139-140, 150-167, https://chicagounbound.uchicago.edu/cgi/ viewcontent.cgi?article $=1052 \&$ context $=$ uclf.

27 See CEDAW Committee, General Recommendation 28, supra note 12, \ 18, discussed infra. 
discrimination women face when different factors combine with their sex and gender to increase their risk to human rights violations. ${ }^{28}$ The CEDAW Committee has also devoted many of its recent General Recommendations to address forms of intersectional discrimination, including women in conflict situations, women with refugee and asylum status, rural women, and the rights of girls. ${ }^{29}$ Can you think of the main advantages and challenges of using the term intersectionality to address the human rights legal challenges faced by women? Which variables can accentuate the women's experience of discrimination?

\section{CEDAW COMMITTEE: DISCRIMINATION AGAINST WOMEN AND STATE OBLIGATIONS}

CEDAW in its Article 17 established an independent monitoring body composed of 23 experts. It is part of the ten treaty-based bodies which form part of the universal system of human rights. The Committee receives and considers reports from state parties and issues concluding observations. It also offers the opportunity for civil society organizations to submit shadow reports.

The Committee can also adopt General Recommendations shedding light on the content of CEDAW dispositions. The Committee has adopted 38 General Recommendations providing important state guidance on issues such as gender-based violence, the role of women in public life, equality in marriage and family relations, temporary special measures, women migrants and those displaced, women and climate change, and other priority issues. ${ }^{30}$

In its General Recommendation 28, the CEDAW Committee provides its most detailed rendition of state obligations under the treaty. It delineates a number of positive and negative obligations of states to prevent, investigate, sanction, and grant reparations for discrimination against women. Some excerpts are included below.

\section{A The core obligations of State parties under Article 2 of the Convention on the Elimination of All Forms of Discrimination against Women}

Committee on the Elimination of Discrimination against Women, General Recommendation 28

U.N. Doc. CEDAW/C/2010/47/GC.2 (2010)

9. Under article 2, States parties must address all aspects of their legal obligations under the Convention to respect, protect and fulfil women's right to non-discrimination and to the enjoyment of equality. The obligation to respect requires that States parties refrain from making laws, policies, regulations, programmes, administrative procedures and

\footnotetext{
28 See id., 118 , discussed infra.

29 See CEDAW Committee General Recommendations 30, 32, 34, and 36, www.ohchr.org/EN/ HRBodies/CEDAW/Pages/Recommendations.aspx (last visited May 19, 2021).

30 See General Recommendations adopted by the CEDAW Committee, www.ohchr.org/EN/ HRBodies/CEDAW/Pages/Recommendations.aspx (last visited on May 19, 2021).
} 
institutional structures that directly or indirectly result in the denial of the equal enjoyment by women of their civil, political, economic, social and cultural rights. The obligation to protect requires that States parties protect women from discrimination by private actors and take steps directly aimed at eliminating customary and all other practices that prejudice and perpetuate the notion of inferiority or superiority of either of the sexes, and of stereotyped roles for men and women. The obligation to fulfil requires that States parties take a wide variety of steps to ensure that women and men enjoy equal rights de jure and de facto, including, where appropriate, the adoption of temporary special measures in line with article 4, paragraph 1, of the Convention and general recommendation No. 25 on article 4, paragraph 1, of the Convention on the Elimination of All Forms of Discrimination against Women, on temporary special measures. This entails obligations of means or conduct and obligations of results. States parties should consider that they have to fulfil their legal obligations to all women through designing public policies, programmes and institutional frameworks that are aimed at fulfilling the specific needs of women leading to the full development of their potential on an equal basis with men.

10. States parties have an obligation not to cause discrimination against women through acts or omissions; they are further obliged to react actively against discrimination against women, regardless of whether such acts or omissions are perpetrated by the State or by private actors. Discrimination can occur through the failure of States to take necessary legislative measures to ensure the full realization of women's rights, the failure to adopt national policies aimed at achieving equality between women and men and the failure to enforce relevant laws. Likewise, States parties have an international responsibility to create and continuously improve statistical databases and the analysis of all forms of discrimination against women in general and against women belonging to specific vulnerable groups in particular. ...

13. Article 2 is not limited to the prohibition of discrimination against women caused directly or indirectly by States parties. Article 2 also imposes a due diligence obligation on States parties to prevent discrimination by private actors. In some cases, a private actor's acts or omission of acts may be attributed to the State under international law. States parties are thus obliged to ensure that private actors do not engage in discrimination against women as defined in the Convention. The appropriate measures that States parties are obliged to take include the regulation of the activities of private actors with regard to education, employment and health policies and practices, working conditions and work standards, and other areas in which private actors provide services or facilities, such as banking and housing. ...

15. The first obligation of States parties referred to in the chapeau of article 2 is the obligation to "condemn discrimination against women in all its forms". States parties have an immediate and continuous obligation to condemn discrimination. They are obliged to proclaim to their population and the international community their total opposition to all forms of discrimination against women to all levels and branches of Government and their determination to bring about the elimination of discrimination against women. The term "discrimination in all its forms" clearly obligates the State party to be vigilant in condemning all forms of discrimination, including forms that are not explicitly mentioned in the Convention or that may be emerging.

16. States parties are under an obligation to respect, protect and fulfil the right to nondiscrimination of women and to ensure the development and advancement of women in order that 
they improve their position and implement their right of de jure and de facto or substantive equality with men. States parties shall ensure that there is neither direct nor indirect discrimination against women. Direct discrimination against women constitutes different treatment explicitly based on grounds of sex and gender differences. Indirect discrimination against women occurs when a law, policy, programme or practice appears to be neutral in so far as it relates to men and women, but has a discriminatory effect in practice on women because pre-existing inequalities are not addressed by the apparently neutral measure. Moreover, indirect discrimination can exacerbate existing inequalities owing to a failure to recognize structural and historical patterns of discrimination and unequal power relationships between women and men.

17. States parties also have an obligation to ensure that women are protected against discrimination committed by public authorities, the judiciary, organizations, enterprises or private individuals, in the public and private spheres. This protection shall be provided by competent tribunals and other public institutions and enforced by sanctions and remedies, where appropriate. States parties should ensure that all Government bodies and organs are fully aware of the principles of equality and non-discrimination on the basis of sex and gender and that adequate training and awareness-raising programmes are set up and carried out in this respect. ...

23. States parties also agree to "pursue by all appropriate means" a policy of eliminating discrimination against women. This obligation to use means or a certain way of conduct gives a State party a great deal of flexibility for devising a policy that will be appropriate for its particular legal, political, economic, administrative and institutional framework and that can respond to the particular obstacles and resistance to the elimination of discrimination against women existing in that State party. Each State party must be able to justify the appropriateness of the particular means it has chosen and demonstrate whether it will achieve the intended effect and result. Ultimately, it is for the Committee to determine whether a State party has indeed adopted all necessary measures at the national level aimed at achieving the full realization of the rights recognized in the Convention.

\section{B Reflections and Questions}

1. Do you see differences between Article 2 of CEDAW and the state obligations described in General Recommendation 28? Is General Recommendation 28 binding on states? CEDAW is a universal treaty containing binding obligations for states that have joined it through ratification and/or accession. As of May 24, 2021, 189 states have ratified CEDAW. Even though CEDAW Committee General Recommendations constitute authoritative interpretations of treaty dispositions, they do not have the legal status of a treaty under international law. They can be considered sources of soft law, persuasive authority on international law, or customary international law in certain instances. ${ }^{31}$

2. CEDAW General Recommendation 28 discusses several layers of obligations states have to address discrimination against women. In paragraph 9, the Committee refers to the obligation to respect, requiring state parties to prevent the adoption of laws and policies which

31 For more reading, see Complance and Commitment: The Role of Non-Binding Instruments in the International Legal System 449-463 (Dinah Shelton, ed., Oxford University Press, 2000). 
may hinder women in their full exercise of their civil, political, economic, social, and cultural rights. States are also mandated to pursue steps to eliminate customary practices which perpetuate discrimination and stereotypes against women. States are also obligated to take steps to ensure that women and men enjoy their rights on the basis of equality - in both theory and practice - in their families, communities, and countries. Which of these obligations are positive and negative in nature? Are these obligations interrelated?

3. CEDAW General Recommendation 28 also clarifies that states have an obligation to eradicate discrimination against women committed not only by states, but also private actors. ${ }^{32}$ CEDAW in Article 2(e) also mandates states to adopt measures to eliminate discrimination against women by any person, organization, or enterprise. CEDAW was one of the first treaties to recognize the human rights implications of private actor activity. Discrimination against women is committed by spouses, partners, family members, employers, corporations, educators, health providers, religious leaders, and many other private actors. Even though international human rights law was adopted to restrain the activity of states, there has been a growing recognition by the international community of the role a diversity of non-state actors plays in human rights violations. Should states be responsible for the actions of private actors? Which criteria should be assessed for a finding of international state responsibility for the acts of an individual, business, education, or health institution? ${ }^{33}$

4. The CEDAW Committee has advanced a very extensive definition of the phrase discrimination against women, confirming in General Recommendation 28 that its protections include women discriminated against on the basis of their sexual orientation and gender identity. ${ }^{34}$ This reflects very important developments in human rights law protecting the rights to non-discrimination, privacy, and judicial protection of women who have suffered unequal treatment due to their sexual orientation, gender identity, and expression. Can you see the advantages of having an expansive view of discrimination against women ${ }^{35}$

5. CEDAW is complemented by an Optional Protocol adopted on October 6, 1999. The Optional Protocol is a separate treaty providing the possibility for states to accept the jurisdiction of the CEDAW Committee to resolve individual case complaints and assume additional obligations under CEDAW. The Optional Protocol entered into force on December 22,2000 , and has been ratified by 114 state parties. $^{36}$

32 See supra CEDAW Committee, General Recommendation 28, supra note 12, $\mathbf{\uparrow}$ | 10, 17.

33 For more reading, see generally Andrew Clapham, Human Rights Obligations for Non-State Actors: Where are We Now?, in Doing Peace the Rights Way: Essays in International Law and Relations in HonOr of Louise Arbour (Fannie Lafontaine and Francoise Larocque, eds., Intersentia, 2017), https://papers.ssrn.com/sol3/papers.cfm?abstract_id=2641390.

34 See supra CEDAW Committee, General Recommendation 28, supra note 12, ๆ 31.

35 For case examples, see Atala Riffo \& Children v. Chile, Merits, Reparations and Costs, Judgment, Inter-Am. Ct. H.R. (ser. C) No. 239, at 86-87 (Feb. 24, 2012), discussed in Chapter 4; E.B. v. France [GC], App. No. 43546/02, Eur. Ct. H.R. (2008); Christine Goodwin v. United Kingdom [GC], App. No. 28957/95, Eur. Ct. H.R. (2002), discussed in Chapter 4.

36 See Optional Protocol to the Convention on the Elimination of Discrimination against Women, G.A. Res. 54/4, annex, 54 U.N. GAOR Supp. (No. 49) at 5, U.N. Doc. A/54/49 (Vol. I) (2000), entered into force Dec. 22, 2000. See Status of Ratifications Interactive Dashboard, Optional Protocol to the Convention on the Elimination of All Forms of Discrimination against Women, https://indicators.ohchr .org/ (last visited on May 24, 2021). 
6. Article 2 of the CEDAW Optional Protocol provides that communications can be submitted by individuals or groups of individuals violating CEDAW Treaty provisions. The CEDAW Committee does assess the admissibility of petitions, and considers whether domestic remedies have been exhausted. States need to be offered an opportunity to remedy the women's rights violations alleged due to the supranational nature of the international human rights system. The case decisions of the CEDAW Committee often include an overview of the facts, legal analysis and findings, as well as recommendations. Under Article 5 of the Optional Protocol, the CEDAW Committee can also issue interim measures to avoid irreparable damage. The CEDAW Committee has issued rulings on cases related to domestic violence and due diligence, access to justice, coerced sterilizations, maternal mortality, and therapeutic abortions, among other issues. ${ }^{37}$

7. Article 4(1) of CEDAW mandates the adoption by states of temporary special measures, with the goal of advancing the equality of men and women in our societies. The measures are intended to address past discrimination, and are part of the strategy to build societies guided by equality. ${ }^{38}$ These measures are only meant to be temporary and should be lifted when their aims have been achieved. They are also supposed to be only part of the strategy or a multisectoral policy to address and curb discrimination against women. There is great freedom in the format and content of these measures, and states have great discretion on how to implement them at the national and local levels. Can you think of areas in which women could really benefit from temporary special measures to have more equal opportunities as compared to men? ${ }^{39}$

\section{Note: CEDAW Committee Inquiry Procedure}

Article 8 of the Optional Protocol authorizes the CEDAW Committee to investigate and document situations of systemic human rights violations. The inquiries undertaken by the CEDAW Committee have provided an important space to issue recommendations to specific states on priority issues concerning the rights of women.

In the case of Northern Ireland, the Committee visited on September 10-19, 2016, and recommended the decriminalization of abortion in all instances.$^{40}$ It also underscored the need

37 For examples of case decisions adopted by the CEDAW Committee, see AT v. Hungary, Communication No. 002/2003, CEDAW/C/36/D/2/2003, January 26, 2005; Sahide Goetcke v. Austria, Communication No. 5/2005, CEDAW/C/39/D/5/2005, August 6, 2007; Fatma Yildirim v. Austria, Communication No. 6/2005, CEDAW/C/39/D/6/2005, October 1, 2007; AS v. Hungary, Communication No. 4/2004, CEDAW/C/36/D/4/2004, August 29, 2006; Alynne Da Silva Pimentel v. Brazil, Communication No. 17/2008, CEDAW/C/49/D/17/2008, August 10, 2011, discussed in Chapter 8; and LC v. Peru, Communication No. 22/2009, CEDAW/C/50/D/22/2009, November 4, 2011.

38 For more discussion on temporary special measures, see General Recommendation No. 25 on Temporary Special Measures, Committee on the Elimination of Discrimination against Women, U.N. Doc. HRI/GEN/1/Rev. 7, ๆ 18-24 (2004).

39 For more reading on the implementation of temporary special measures, see Asian Development Bank, Guidance Note on Gender and the Law: Temporary Special Measures to Promote Gender Equality, June 2012, at 5-8, www.adb.org/sites/default/files/institutional-document/33634/files/guidance-note -gender-and-law.pdf.

40 See generally Committee on the Elimination of Discrimination against Women, Report of the Inquiry Concerning Canada of the Committee on the Elimination of Discrimination against Women under Article 8 of the Optional Protocol to the Convention on the Elimination of All Forms of Discrimination 
for all state parties not to penalize women resorting to abortions ${ }^{41}$ Since then, the United Kingdom and Northern Ireland have undertaken a legal process to decriminalize abortion in Northern Ireland. ${ }^{42}$

The Committee also performed an inquiry related to missing and disappeared aboriginal women in Canada. ${ }^{43}$ The Committee visited Canada on September 9-13, 2013, and emphasized in its final report the extreme nature of the violence suffered by aboriginal women, its connection with colonial and post-colonial policies, and the long-lasting socio-economic marginalization of aboriginal peoples. ${ }^{44}$ Due to these social conditions, aboriginal women are more exposed to violence and affected by the state failure to guarantee justice in these cases. ${ }^{45}$

One of the most well-known inquiries completed by the CEDAW Committee was to Ciudad Juárez, Mexico, to examine the situation of missing and murdered women in this locality. ${ }^{46}$ The CEDAW Committee visited Mexico on October 18-26, 2003, and expressed its concern over the systemic pattern of gender-based violence and killings in this locality, fueled by a culture of violence, discrimination, and impunity. ${ }^{47}$ Among several statements, the Committee recommended to the state to integrate a gender perspective in all investigations and prevention policies to combat violence, and to adopt programs to restore the social fabric..$^{48}$

\section{UNIVERSAL HUMAN RIGHTS TREATIES: THE COVENANTS AND BEYOND}

Even though CEDAW is the leading treaty in the world concerning the rights of women, the universal regional human rights treaties contain important dispositions that protect the rights of women to non-discrimination and equality. From these, two of the most important are the International Covenant on Civil and Political Rights (hereinafter "ICCPR") and the International Covenant on Economic, Social and Cultural Rights (hereinafter "ICESCR"). These treaties codify key rights, and both positive and negative obligations states have to

against Women, CEDAW/C/OP.8/CAN/1 (Mar. 30, 2015) (hereinafter CEDAW Committee, Inquiry Report on Canada).

${ }_{41}$ See Committee on the Elimination of Discrimination against Women, Report of the Inquiry concerning the United Kingdom of Great Britain and Northern Ireland under Article 8 of the Optional Protocol to the Convention on the Elimination of All Forms of Discrimination against Women, CEDAW/C/Op.8/GBR/1 (March 6, 2018), $₫ 58$.

42 See Henry McDonald, Northern Ireland Confirms that Abortions Can Now Be Carried Out, The Guardian, April 9, 2020, www.theguardian.com/world/2020/apr/09/northern-ireland-confirms -abortions-can-now-be-carried-out (last visited on September 24, 2021); Suyin Hayes, After 158 Years U.K. Lawmakers Have Voted to Decriminalize Abortion in Northern Ireland. The Fight's Not Over Yet, TIME, July 25, 2019, https://time.com/5634762/northern-ireland-abortion-law-impact/ (last visited on September 24, 2021).

43 See generally CEDAW Committee, Inquiry Report on Canada, supra note 40.

44 See id., $9 \uparrow$ 201-204.

45 See id., 9 甲 201-204.

46 See generally Committee on the Elimination of all Forms of Discrimination against Women, Report on Mexico produced by the Committee on the Elimination of Discrimination against Women under Article 8 of the Optional Protocol to the Convention, and reply from the Government of Mexico, CEDAW/C/2005/OP.8/MEXICO (Jan. 27, 2005).

47 See id., 19 260-262, 268.

48 See id. 
protect, respect, and fulfill the human rights of women. The excerpts below exemplify the positive and negative obligations advanced by the ICCPR and the ICESCR.

\section{A International Covenant on Civil and Political Rights}

999 U.N.T.S. 171, entered into force Mar. 23, 1976

\section{PREAMBLE}

The States Parties to the present Covenant,

Considering that, in accordance with the principles proclaimed in the Charter of the United Nations, recognition of the inherent dignity and of the equal and inalienable rights of all members of the human family is the foundation of freedom, justice and peace in the world,

Recognizing that these rights derive from the inherent dignity of the human person,

Recognizing that, in accordance with the Universal Declaration of Human Rights, the ideal of free human beings enjoying civil and political freedom and freedom from fear and want can only be achieved if conditions are created whereby everyone may enjoy his civil and political rights, as well as his economic, social and cultural rights,

Considering the obligation of States under the Charter of the United Nations to promote universal respect for, and observance of, human rights and freedoms,

Realizing that the individual, having duties to other individuals and to the community to which he belongs, is under a responsibility to strive for the promotion and observance of the rights recognized in the present Covenant,

Agree upon the following articles:

$\ldots$

\section{Article 2}

1. Each State Party to the present Covenant undertakes to respect and to ensure to all individuals within its territory and subject to its jurisdiction the rights recognized in the present Covenant, without distinction of any kind, such as race, colour, sex, language, religion, political or other opinion, national or social origin, property, birth or other status.

2. Where not already provided for by existing legislative or other measures, each State Party to the present Covenant undertakes to take the necessary steps, in accordance with its constitutional processes and with the provisions of the present Covenant, to adopt such legislative or other measures as may be necessary to give effect to the rights recognized in the present Covenant. ...

\section{Article 3}

The States Parties to the present Covenant undertake to ensure the equal right of men and women to the enjoyment of all civil and political rights set forth in the present Covenant. ...

\section{Article 6}

1. Every human being has the inherent right to life. This right shall be protected by law. No one shall be arbitrarily deprived of his life.... 
No one shall be subjected to torture or to cruel, inhuman or degrading treatment or punishment. In particular, no one shall be subjected without his free consent to medical or scientific experimentation.

\section{Article 8}

1. No one shall be held in slavery; slavery and the slave-trade in all their forms shall be prohibited.

2. No one shall be held in servitude.

\section{Article 9}

1. Everyone has the right to liberty and security of person. No one shall be subjected to arbitrary arrest or detention. No one shall be deprived of his liberty except on such grounds and in accordance with such procedure as are established by law. ...

\section{Article 14}

1. All persons shall be equal before the courts and tribunals. In the determination of any criminal charge against him, or of his rights and obligations in a suit at law, everyone shall be entitled to a fair and public hearing by a competent, independent and impartial tribunal established by law....

\section{Article 17}

1. No one shall be subjected to arbitrary or unlawful interference with his privacy, family, home or correspondence, nor to unlawful attacks on his honour and reputation....

\section{Article 18}

1. Everyone shall have the right to freedom of thought, conscience and religion....

\section{Article 21}

The right of peaceful assembly shall be recognized. No restrictions may be placed on the exercise of this right other than those imposed in conformity with the law and which are necessary in a democratic society in the interests of national security or public safety, public order (ordre public), the protection of public health or morals or the protection of the rights and freedoms of others.

\section{Article 22}

1. Everyone shall have the right to freedom of association with others, including the right to form and join trade unions for the protection of his interests. ...

\section{Article 26}

All persons are equal before the law and are entitled without any discrimination to the equal protection of the law. In this respect, the law shall prohibit any discrimination and guarantee to 
all persons equal and effective protection against discrimination on any ground such as race, colour, sex, language, religion, political or other opinion, national or social origin, property, birth or other status.

\section{Article 27}

In those States in which ethnic, religious or linguistic minorities exist, persons belonging to such minorities shall not be denied the right, in community with the other members of their group, to enjoy their own culture, to profess and practise their own religion, or to use their own language.

\section{B International Covenant on Economic, Social and Cultural Rights}

993 U.N.T.S. 3, entered into force Jan. 3, 1976

\section{PREAMBLE}

The States Parties to the present Covenant,

Considering that, in accordance with the principles proclaimed in the Charter of the United Nations, recognition of the inherent dignity and of the equal and inalienable rights of all members of the human family is the foundation of freedom, justice and peace in the world,

Recognizing that these rights derive from the inherent dignity of the human person,

Recognizing that, in accordance with the Universal Declaration of Human Rights, the ideal of free human beings enjoying freedom from fear and want can only be achieved if conditions are created whereby everyone may enjoy his economic, social and cultural rights, as well as his civil and political rights,

Considering the obligation of States under the Charter of the United Nations to promote universal respect for, and observance of, human rights and freedoms,

Realizing that the individual, having duties to other individuals and to the community to which he belongs, is under a responsibility to strive for the promotion and observance of the rights recognized in the present Covenant,

Agree upon the following articles:

\section{Article 2}

1. Each State Party to the present Covenant undertakes to take steps, individually and through international assistance and co-operation, especially economic and technical, to the maximum of its available resources, with a view to achieving progressively the full realization of the rights recognized in the present Covenant by all appropriate means, including particularly the adoption of legislative measures.

2. The States Parties to the present Covenant undertake to guarantee that the rights enunciated in the present Covenant will be exercised without discrimination of any kind as to race, colour, sex, language, religion, political or other opinion, national or social origin, property, birth or other status. ...

\section{Article 3}

The States Parties to the present Covenant undertake to ensure the equal right of men and women to the enjoyment of all economic, social and cultural rights set forth in the present Covenant. ... 


\section{Article 6}

The States Parties to the present Covenant recognize the right to work, which includes the right of everyone to the opportunity to gain his living by work which he freely chooses or accepts, and will take appropriate steps to safeguard this right.

\section{Article 7}

The States Parties to the present Covenant recognize the right of everyone to the enjoyment of just and favourable conditions of work which ensure, in particular:

(a) Remuneration which provides all workers, as a minimum, with:

(i) Fair wages and equal remuneration for work of equal value without distinction of any kind, in particular women being guaranteed conditions of work not inferior to those enjoyed by men, with equal pay for equal work; ...

\section{Article 9}

The States Parties to the present Covenant recognize the right of everyone to social security, including social insurance.

\section{Article 10}

The States Parties to the present Covenant recognize that:

1. The widest possible protection and assistance should be accorded to the family, which is the natural and fundamental group unit of society, particularly for its establishment and while it is responsible for the care and education of dependent children. Marriage must be entered into with the free consent of the intending spouses.

2. Special protection should be accorded to mothers during a reasonable period before and after childbirth. During such period working mothers should be accorded paid leave or leave with adequate social security benefits.

\section{Article 11}

1. The States Parties to the present Covenant recognize the right of everyone to an adequate standard of living for himself and his family, including adequate food, clothing and housing, and to the continuous improvement of living conditions. The States Parties will take appropriate steps to ensure the realization of this right, recognizing to this effect the essential importance of international co-operation based on free consent. ...

\section{Article 12}

1. The States Parties to the present Covenant recognize the right of everyone to the enjoyment of the highest attainable standard of physical and mental health. ...

\section{Article 13}

1. The States Parties to the present Covenant recognize the right of everyone to education. They agree that education shall be directed to the full development of the human personality and the sense of its dignity, and shall strengthen the respect for human rights and 
fundamental freedoms. They further agree that education shall enable all persons to participate effectively in a free society, promote understanding, tolerance and friendship among all nations and all racial, ethnic or religious groups, and further the activities of the United Nations for the maintenance of peace. ...

\section{Article 15}

1. The States Parties to the present Covenant recognize the right of everyone:

(a) To take part in cultural life;

(b) To enjoy the benefits of scientific progress and its applications;

(c) To benefit from the protection of the moral and material interests resulting from any scientific, literary or artistic production of which he is the author.

\section{Reflections and Questions}

1. Under international human rights law, states have the negative obligation to refrain from committing human rights violations which may contravene CEDAW. States are also mandated to adopt positive measures exemplified in legislation, policies, programs, and services to build societies free from discrimination. ${ }^{49}$ Consider examples of negative and positive steps that states can adopt to comply with their human rights obligations towards women. Are these obligations connected? What are their similarities and differences?

2. The International Covenant on Civil and Political Rights (hereinafter "ICCPR") contains some of the most important foundational and individual rights of the international human rights law system. It is a document very inspired by the Universal Declaration of Human Rights. The ICCPR codifies the rights to life, to be free from torture and slavery, freedom of thought and religion, the rights to free expression and association, and the obligation not to discriminate against all persons, and religious and linguistic minorities. The International Covenant on Economic, Social and Cultural Rights (hereinafter "ICESCR") includes instead rights of a wider and more systemic nature in their implementation and scope, including the rights to health, social security, and education, among others. Are civil and political rights connected to economic, social, and cultural rights ${ }^{50}$ Consider concrete examples of the indivisibility and interconnectedness of civil, political, economic, social, and cultural rights.

3. Do you see any differences in the language of the ICCPR and the ICESCR contained in their Article 2? The International Covenant on Civil and Political Rights codifies an immediate obligation for states to respect and ensure all rights within the Covenant. The International Covenant on Economic Social and Cultural Rights instead acknowledges the

49 For more reading on positive and negative obligations under international human rights law, see General Comment 31 on the Nature of the General Legal Obligation Imposed on States Parties to the Covenant on Civil and Political Rights, Human Rights Committee, U.N. Doc. CCPR/C/21/Rev.1/Add.13 (2004), 9 1 3-16; Hurst Hannum, Dinah Shelton, S. James and Rosa Celorio, Who Has Legal Obligations under International Human Rights Law?, in International Human Rights; Problems of Law, Policy, AND Practice 335-461 (Wolters Kluwer Publishers, 6th ed., 2017).

50 For more reading, see Flavia Piovesan, Social, Economic and Cultural Rights and Civil and Political Rights, 1 Sur - INT'L J. on Hum. RTs. 21, 21-33 (2004). 
limitations in resources that states may have to immediately implement economic, social, and cultural rights. In this sense, the ICESCR reflects the principle of progressive realization in its Article 2. Nevertheless, the Committee on Economic, Social and Cultural Rights has clarified that states do have an immediate obligation to take concrete steps to fulfill the rights in the ICESCR and to not regress on advances made. ${ }^{51}$

4. Both the Human Rights Committee and the Economic, Social and Cultural Rights Committee have pronounced over the key nature of the obligation not to discriminate when it comes to women. The Human Rights Committee in its General Comment 28 underscores the immediate nature of pursuing the equality of men and women under Article 3 of the ICCPR and the obligation to respect and ensure the rights of women to live free from all forms of discrimination and violence. The Economic, Social and Cultural Rights Committee also adopted its General Comment 16, in which it underscores the connection between the obligations not to discriminate and to pursue equality under the ICESCR, and how these are paramount to full compliance of economic, social, and cultural rights. The ESCR Committee also discusses how these obligations are connected to all rights in the ICESCR, including the rights to work, to form trade unions, to social security, to health, and to culture. ${ }^{52}$

$* * * * *$

The International Covenant on Civil and Political Rights is monitored by the Human Rights Committee, which is composed of independent experts who assess the quality of implementation by the state parties. States can assume additional obligations before the Human Rights Committee by ratifying the First Optional Protocol to the ICCPR, recognizing the competence of the Committee to receive individual communications from victims of human rights violations. ${ }^{53}$

The Committee historically has considered individual communications addressing women's rights and gender equality issues. Copied below are excerpts from a recent decision by the Human Rights Committee concerning the matter of Sharon McIvor and Jacob Grismer, affecting aboriginal women in Canada, and the equality of their rights before the law.

\section{Sharon McIvor and Jacob Grismer}

Human Rights Committee, Views on Communication 2020/2010

CCPR/C/124/D/2020/2010 (2019)

51 For more reading, see General Comment 3 on the Nature of States Parties' Obligations (Art. 2, para. 1, of the Covenant), Committee on Economic, Social and Cultural Rights, U.N. Doc. HRI/GEN/1/ Rev.6 at 14, $1 \uparrow$ 2, 9-13 (2003).

52 See General Comment 28 on the Equality of Rights between Men and Women, Human Rights Committee, U.N. Doc. CCPR/C/21/Rev.1/Add.10, ๆ 5-9, 18-32 (2000); General Comment 16 on the Equal Right of Men and Women to the Enjoyment of All Economic, Social and Cultural Rights (Art. 3 of the International Covenant on Economic, Social and Cultural Rights), Committee on Economic, Social and Cultural Rights, E/C.12/2005/4, 9 T 22-31 (2005).

53 See First Optional Protocol to the International Covenant on Civil and Political Rights, General Assembly Resolution 2200A (XXI) of 16 December 1966, entry into force 23 March 1976, in accordance with Article 9, Article 1. 
This communication was presented by Sharon McIvor and her son Jacob Grismer. They are both nationals from Canada and members of the First Nations in Merritt, British Columbia. They alleged concretely before the Human Rights Committee that the granting by Canadian law of Indian Status based on the patrilineal line, to the exclusion of the matrilineal line, contravened the ICCPR and their human rights. They raised violations of their rights to non-discrimination, equality, and culture under Articles 2(1), 3(a), 26, and 27 of the ICCPR.

7.6 The Committee recalls that the principle of equal treatment of the sexes applies by virtue of articles 2(1), 3 and 26.21. It further recalls its General Comment No. 18 on nondiscrimination, according to which the Covenant prohibits any distinction, exclusion, restriction or preference which is based on any ground including sex, and which has the purpose or effect of nullifying or impairing the recognition, enjoyment or exercise by all persons, on an equal footing, of all rights and freedoms. In the present case, the Committee notes that the Indian Act as amended in 1985, 2011 and 2017 still incorporates a distinction based on sex. It further notes that according to the State party, this distinction will be eliminated, and all persons in the maternal line will be entitled to the same status as persons in the paternal line, when the additional provision in Bill S-3 comes into force. The Committee considers, however, that at the present time, those amendments are not yet in force, and the distinction based on sex still persists in the Indian Act. The Committee further notes that the domestic courts also found that section 6 of the 1985 Indian Act was discriminatory after the 2011 amendments.

7.7 The Committee recalls its General Comment No. 18 and its jurisprudence that not every differentiation amounts to discrimination, as long as it is based on reasonable and objective criteria, in pursuit of an aim that is legitimate under the Covenant. The test for the Committee therefore is whether, in the circumstances of the present communication, the distinction based on sex in the Indian Act, as amended, meets the criteria of reasonableness, objectivity and legitimacy of aim. ...

7.10 The Committee recalls its General Comment No. 23 (1994) that article 27 establishes and recognizes a right which is conferred on individuals belonging to indigenous groups and which is distinct from, and additional to, the other rights which all persons are entitled to enjoy under the Covenant. Culture manifests itself in many forms, including a particular way of life associated with the use of land resources, especially in the case of indigenous peoples, which may include such traditional activities as fishing and hunting. Positive measures of protection are, therefore, required not only against the acts of the State party itself, whether through its legislative, judicial or administrative authorities, but also against the acts of other persons within the State party.

7.11 The Committee further recalls that the prohibition on discrimination in the Covenant applies not only to discrimination in law, but also to discrimination in fact, whether practiced by public authorities, by the community, or by private persons or bodies. It further recalls that the principle of equality sometimes requires States parties to adopt temporary special measures in order to diminish or eliminate conditions that cause or help to perpetuate discrimination prohibited by the Covenant. In the present case, the State party acknowledges both that differential treatment based on status exists, and that the additional provisions of Bill S-3 that are not yet in force will entitle persons in the maternal line to the 
same status as those in the paternal line. The Committee also notes the State party's argument that the distinction based on sex existing in the different sub-paragraphs of section 6(1) of the 1985 Indian Act, as amended, is justified by the legitimate aim of preservation of acquired rights. However, the State party has not demonstrated how recognizing equal status for the authors under section 6(1)(a) would adversely affect the acquired rights of others. The State party therefore has failed to demonstrate that the stated aim is based on objective and reasonable grounds. The Committee accordingly concludes that the continuing distinction based on sex in section 6(1) of the Indian Act constitutes discrimination, which has impacted the right of the authors to enjoy their own culture together with the other members of their group. The Committee therefore concludes that the authors have demonstrated a violation of articles 3 and 26, read in conjunction with article 27 of the Covenant.

7.12 In the light of the previous findings, the Committee considers that it is not necessary to examine the authors' remaining claims under the Covenant.

\section{E Reflections and Questions}

1. Which connections can you find in the case of Sharon McIvor and Jacob Grismer between the civil and political rights and the economic, social, and cultural rights of women?

2. General Comment 18 of the Human Rights Committee discusses the content of the obligation not to discriminate under the International Covenant on Civil and Political Rights codified in Article 2(1). In its analysis, the Human Rights Committee adopts the CEDAW treaty definition of discrimination in Article 1 discussed earlier in this chapter, and expands it to distinctions, exclusions, restrictions and preferences motivated by race, color, national origin, and other factors. The Human Rights Committee also refers to the definition of racial discrimination advanced by the International Convention on the Elimination of All Forms of Racial Discrimination (hereinafter "CERD") in its Article 1(1), prohibiting distinctions on the basis of race, color, descent, national, and ethnic origin. ${ }^{54}$

3. In the matter concerning Sharon McIvor and Jason Grismer, the Human Rights Committee indicates that distinctions based on sex must meet the criteria of "reasonableness, objectivity, and legitimacy of aim." The test for the Committee therefore is whether in the circumstances of the present communication, the distinction based on sex in the Indian Act, as amended, meets the criteria of reasonableness, objectivity, and legitimacy of aim. ${ }^{55} \mathrm{Can}$ you think of any distinctions on the basis of sex that can meet these criteria?

4. The structural discrimination against indigenous women on the basis of their sex, gender, and race in Canada has garnered wide international attention and reporting. One of the most important reports was adopted by the Inter-American Commission on Human Rights after its visit to Canada to study the situation of missing and murdered aboriginal women

54 See General Comment 18 on Non-Discrimination, Human Rights Committee, U.N. Doc. HRI/ GEN/1/Rev.1 at 26, 9 6-7 (1994); International Convention on the Elimination of All Forms of Racial Discrimination, 660 U.N.T.S. 195, entered into force Jan. 4, 1969.

55 See Human Rights Committee, Matter of Sharon McIvor and Jason Grismer, supra at para. 7.7. 
on August 6-9 of 2013. ${ }^{56}$ The resulting report documents how indigenous women and girls in Canada have been murdered or disappeared at a rate four times higher than the rate of representation of indigenous women in the Canadian population. ${ }^{57}$ The report discusses as important causes the long history of discrimination against indigenous women in Canada, including obstacles to the proper recognition of their Aboriginal Status under the Indian Act, and forced enrollment in residential schools. ${ }^{58}$ These factors contributed to the separation of indigenous women from their cultural heritage, families, and communities. Indigenous women are still affected by high levels of poverty, economic marginalization, and inadequate housing; all economic and social factors which expose them to violence. ${ }^{59}$

\section{DISCRIMINATION ON THE BASIS OF SEX AT THE NATIONAL LEVEL}

Some of the most important work to address the rights of women is done at the national level and by domestic courts. In the case of the United States in particular, its Supreme Court has adopted a series of rulings, discussed throughout this casebook, advancing important content to the obligations not to discriminate, equality, liberty, and privacy under the United States Constitution. This national work is important as the universal and regional treaties and mechanisms discussed in this casebook are supranational, and meant to serve only as a second avenue for justice when the national institutions fail to prevent and offer an adequate remedy for women's rights violations. The administration of justice at the national level can serve as an important layer of protection for the rights of women when other state institutions and private actors perpetuate violations of women's rights. ${ }^{60}$ This protection can occur in federal, state, city, and municipal courts, and in the civil, criminal, and administrative spheres.

As a country example, this section in particular discusses the treatment of discrimination on the basis of sex by the United States Supreme Court. The section also comments on the legacy of female jurists in United States courts and that particularly of the late Justice Ruth Bader Ginsburg.

Our discussion begins with excerpts from the decision in the case of United States $v$. Virginia by the United States Supreme Court, whose majority opinion was authored by Justice Ruth Bader Ginsburg. The case addresses the male-only admissions policy at the Virginia Military Institute. The United States sued Virginia and the Virginia Military Institute, claiming that the exclusively male admissions policy violated the Fourteenth Amendment's Equal Protection Clause. The United States presented the lawsuit in 1990, after a complaint was filed

56 Inter-American Commission on Human Rights, Missing and Murdered Indigenous Women in British Columbia, Canada, OEA/Ser.L/V/II. Doc. 30/14, Executive Summary.

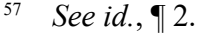

58 See id., $₫$ ๆ 77-101.

59 See id., $\uparrow \uparrow 1-15$.

60 For more discussion on how constitutional litigation can be used to advance gender equality issues, see Beverly Baines and Ruth Rubio-Marin, Toward a Feminist Constitutional Agenda, in The Gender of Constitutional Jurisprudence 1-21 (Beverly Baines and Ruth Rubio-Marin eds., Cambridge University Press, 2005). 
with the Attorney General by a female high-school student seeking admission to the Virginia Military Institute. ${ }^{61}$

\section{A United States v. Virginia}

518 U.S. 515 (1996)

Justice Ginsburg delivered the opinion of the Court

... Founded in 1839, VMI is today the sole single sex school among Virginia's 15 public institutions of higher learning. VMI's distinctive mission is to produce "citizen soldiers," men prepared for leadership in civilian life and in military service. VMI pursues this mission through pervasive training of a kind not available anywhere else in Virginia. Assigning prime place to character development, VMI uses an "adversative method" modeled on English public schools and once characteristic of military instruction. VMI constantly endeavors to instill physical and mental discipline in its cadets and impart to them a strong moral code. The school's graduates leave VMI with heightened comprehension of their capacity to deal with duress and stress, and a large sense of accomplishment for completing the hazardous course.

VMI has notably succeeded in its mission to produce leaders; among its alumni are military generals, Members of Congress, and business executives. The school's alumni overwhelmingly perceive that their VMI training helped them to realize their personal goals. VMI's endowment reflects the loyalty of its graduates; VMI has the largest per student endowment of all undergraduate institutions in the Nation. ...

In 1990, prompted by a complaint filed with the Attorney General by a female high school student seeking admission to VMI, the United States sued the Commonwealth of Virginia and VMI, alleging that VMI's exclusively male admission policy violated the Equal Protection Clause of the Fourteenth Amendment. ...

In the two years preceding the lawsuit, the District Court noted, VMI had received inquiries from 347 women, but had responded to none of them. ...

In response to the Fourth Circuit's ruling, Virginia proposed a parallel program for women: Virginia Women's Institute for Leadership (VWIL). The 4-year, state sponsored undergraduate program would be located at Mary Baldwin College, a private liberal arts school for women, and would be open, initially, to about 25 to 30 students. Although VWIL would share VMI's mission - to produce "citizen soldiers"- the VWIL program would differ, as does Mary Baldwin College, from VMI in academic offerings, methods of education, and financial resources....

The average combined SAT score of entrants at Mary Baldwin is about 100 points lower than the score for VMI freshmen. ... Mary Baldwin's faculty holds "significantly fewer Ph.D.'s than the faculty at VMI ..." and receives significantly lower salaries. ...While VMI offers degrees in liberal arts, the sciences, and engineering, Mary Baldwin, at the time of trial, offered only bachelor of arts degrees. ... A VWIL student seeking to earn an engineering degree could gain one, without public support, by attending Washington University in St. Louis, Missouri, for two years, paying the required private tuition. ...

${ }^{61}$ See United States v. Virginia, 518 U.S. 515, 523 (1996). 
Today's skeptical scrutiny of official action denying rights or opportunities based on sex responds to volumes of history. As a plurality of this Court acknowledged a generation ago, "our Nation has had a long and unfortunate history of sex discrimination." Frontiero v. Richardson, 411 U.S. 677, 684 (1973). Through a century plus three decades and more of that history, women did not count among voters composing "We the People"; ... not until 1920 did women gain a constitutional right to the franchise. ... And for a half century thereafter, it remained the prevailing doctrine that government, both federal and state, could withhold from women opportunities accorded men so long as any "basis in reason" could be conceived for the discrimination....

In 1971, for the first time in our Nation's history, this Court ruled in favor of a woman who complained that her State had denied her the equal protection of its laws. Reed v. Reed, 404 U.S. 71, 73 (holding unconstitutional Idaho Code prescription that, among "“several persons claiming and equally entitled to administer [a decedent's estate], males must be preferred to females"'). Since Reed, the Court has repeatedly recognized that neither federal nor state government acts compatibly with the equal protection principle when a law or official policy denies to women, simply because they are women, full citizenship stature-equal opportunity to aspire, achieve, participate in and contribute to society based on their individual talents and capacities. ...

Without equating gender classifications, for all purposes, to classifications based on race or national origin ... the Court, in post-Reed decisions, has carefully inspected official action that closes a door or denies opportunity to women (or to men). ... To summarize the Court's current directions for cases of official classification based on gender: Focusing on the differential treatment or denial of opportunity for which relief is sought, the reviewing court must determine whether the proffered justification is "exceedingly persuasive." The burden of justification is demanding and it rests entirely on the State. See Mississippi Univ. for Women, 458 U. S., at 724. The State must show "at least that the [challenged] classification serves 'important governmental objectives and that the discriminatory means employed' are 'substantially related to the achievement of those objectives." '... The justification must be genuine, not hypothesized or invented post hoc in response to litigation. And it must not rely on overbroad generalizations about the different talents, capacities, or preferences of males and females....

The heightened review standard our precedent establishes does not make sex a proscribed classification. Supposed "inherent differences" are no longer accepted as a ground for race or national origin classifications. See Loving v. Virginia, 388 U.S. 1 (1967). Physical differences between men and women, however, are enduring: "[T]he two sexes are not fungible; a community made up exclusively of one [sex] is different from a community composed of both." Ballard v. United States, 329 U.S. 187, 193 (1946)....

Measuring the record in this case against the review standard just described, we conclude that Virginia has shown no "exceedingly persuasive justification" for excluding all women from the citizen soldier training afforded by VMI. We therefore affirm the Fourth Circuit's initial judgment, which held that Virginia had violated the Fourteenth Amendment's Equal Protection Clause. Because the remedy proffered by Virginia-the Mary Baldwin VWIL program - does not cure the constitutional violation, i.e., it does not provide equal opportunity, we reverse the Fourth Circuit's final judgment in this case. ...

Single sex education affords pedagogical benefits to at least some students, Virginia emphasizes, and that reality is uncontested in this litigation. Similarly, it is not disputed that diversity 
among public educational institutions can serve the public good. But Virginia has not shown that VMI was established, or has been maintained, with a view to diversifying, by its categorical exclusion of women, educational opportunities within the State. In cases of this genre, our precedent instructs that "benign" justifications proffered in defense of categorical exclusions will not be accepted automatically; a tenable justification must describe actual state purposes, not rationalizations for actions in fact differently grounded. ...

In myriad respects other than military training, VWIL does not qualify as VMI's equal. VWIL's student body, faculty, course offerings, and facilities hardly match VMI's. Nor can the VWIL graduate anticipate the benefits associated with VMI's 157-year history, the school's prestige, and its influential alumni network. ...

VMI, too, offers an educational opportunity no other Virginia institution provides, and the school's "prestige" - associated with its success in developing "citizen soldiers"-is unequaled. Virginia has closed this facility to its daughters and, instead, has devised for them a "parallel program," with a faculty less impressively credentialed and less well paid, more limited course offerings, fewer opportunities for military training and for scientific specialization. ... VMI, beyond question, "possesses to a far greater degree" than the VWIL program "those qualities which are incapable of objective measurement but which make for greatness in a ... school," including "position and influence of the alumni, standing in the community, traditions and prestige." ...

A prime part of the history of our Constitution, historian Richard Morris recounted, is the story of the extension of constitutional rights and protections to people once ignored or excluded. VMI's story continued as our comprehension of "We the People" expanded ... There is no reason to believe that the admission of women capable of all the activities required of VMI cadets would destroy the Institute rather than enhance its capacity to serve the "more perfect Union."

For the reasons stated, the initial judgment of the Court of Appeals ... is affirmed, the final judgment of the Court of Appeals ... is reversed, and the case is remanded for further proceedings consistent with this opinion.

\section{B Reflections and Questions}

1. Former Justice Ruth Bader Ginsburg, who served in the United States Supreme Court for 27 years and passed away on September 18, 2020, was one of the most influential jurists of her generation on gender equality issues. Prior to her time in the United States Supreme Court, she became famous for litigating successfully a series of emblematic cases on sex-based discrimination. As a Justice of the United States Supreme Court, she was a leader of its liberal wing, advocating in her majority and dissenting opinions for the rights of women, racial groups, and those marginalized. She also co-founded the American Civil Liberties Union's Women's Rights Project and was a law professor. Her life story and the obstacles she faced to secure a job upon graduation from Columbia Law School due to her sex motivated much of her legal work on behalf of women. ${ }^{62}$

62 For more reading on the legacy of the work of former Justice Ruth Bader Ginsburg in the treatment of gender equality issues by United States Courts, see generally Deborah Jones Merritt and David M. Lieberman, Ruth Bader Ginsburg's Jurisprudence of Opportunity and Equality, 104 CoLUM. L. REV. 39 (2004). 
2. Distinctions on the basis of sex have been historically reviewed by the United States Supreme Court with an intermediate level of scrutiny, which is not as strict as the legal standard applied to classifications on the basis of race. In Craig v. Boren, the United States Supreme Court established in 1976 that gender classifications must advance important governmental objectives and must be "substantially related" to the achievement of those objectives to be in accordance with the Equal Protection Clause of the Fourteenth Amendment of the U.S. Constitution. See, Craig v. Boren, 429 U.S. 190, 197 (1976). In United States v. Virginia, the United States Supreme Court established that states must advance an "exceedingly persuasive justification" to justify a gender-based distinction. Is the standard of review advanced by Justice Ginsburg and the majority opinion in United States $v$. Virginia consistent with intermediate scrutiny? Should gender-based classifications be subjected to as strict scrutiny as those based on race?

3. Reflect on the questions below related to the United States $v$. Virginia decision:

a. Is it relevant to the discrimination analysis in this case that the Virginia Military Institute is a public institution?

b. Do you think that this case would have had a different outcome if a military educational program of comparable quality had been available for women?

c. Were new rights for women created by this decision?

4. The United States Supreme Court has not historically referred to international law when ruling on cases related to the human rights of women. The United States has also not ratified CEDAW. Can you think of reasons why it would be useful for the United States to ratify CEDAW? If ratified, would it be useful for United States Courts to refer to CEDAW principles and obligations? Does it matter whether international law is applied by domestic courts when ruling on cases advancing the rights of women?

5. Do female judges have a special obligation to advance women's rights in their rulings? Is a progressive notion of the content of the United States Constitution always necessary to respect and ensure human rights?

\section{Note and exercise: The complicated history of the Equal Rights Amendment in the United States}

Even though the United States Constitution does include the Equal Protection Clause in its Fourteenth Amendment, it is devoid of any explicit provision recognizing equality between the sexes. The complicated process of adopting an Equal Rights Amendment to the United States Constitution has been part of the historical struggle to achieve equal protection of the law for women in the United States. Even though the Equal Rights Amendment was first introduced by the National Woman's Party in 1923, it gained real momentum in Congress between 1971 and 1972. It was approved in 1971 by the U.S. House of Representatives and in 1972 by the United States Senate. This was a key achievement by the growing feminist movement in the United States. Conservative backlash, however, impeded final ratification of the Equal Rights Amendment, falling short of the required 38 states needed for this purpose. ${ }^{63}$ Most recently,

63 For a response to the arguments against the Equal Rights Amendment, and analysis of its potential impact on legislation which differentiates on the basis of sex, see Ruth Bader Ginsburg, The Need for the Equal Rights Amendment, 59 A.B.A. J. 1013, 1014-1019 (1973). 
discussions over the potential adoption of the Equal Rights Amendment have been revived again, particularly after the MeToo movement, discussed in Chapter 6 of this casebook. ${ }^{64}$ States like Nevada, Illinois, and Virginia have ratified the Equal Rights Amendment recently. ${ }^{65}$

Consider the implications of the potential ratification of the Equal Rights Amendment. In this regard, contemplate the following questions:

a. What do you think would be the impact of passing the Equal Rights Amendment in the work of the U.S. Supreme Court and lower courts?

b. Do you think an Equal Rights Amendment would motivate the United States Supreme Court to apply strict scrutiny to cases alleging discrimination on the basis of sex?

c. What would be the effect of the passage of the Equal Rights Amendments on current legislation?

d. Can you think of contemporary problems in the United States that are connected to discrimination against women? How do you think adoption of the Amendment would help address discrimination against women in key sectors such as education, employment, community, family, and in political life?

e. Do constitutional protection and litigation make a difference to respect, protect, and fulfill the equality of women?

f. Should the Equal Rights Amendment be limited solely to discrimination on the basis of sex? What about discrimination on the basis of gender and the concerns of LGBTI groups?

\section{STEREOTYPES AND CULTURAL PATTERNS OF BEHAVIOR}

One of the most important legacies of CEDAW is that it addresses in the text of the treaty the issue of stereotypes and socio-cultural patterns of behavior that work socially to the detriment of women. Stereotypes are referred to in Article 5 of the text of CEDAW, which posits that states should adopt measures to modify social and cultural patterns and prejudices based on stereotyped roles for men and women. Article 2(f) of CEDAW moreover mandates states to adopt measures to address existing customs and practices which constitute discrimination against women both in law and in practice. Article 10(c) additionally provides that states should eliminate stereotypes in education and teaching methods.

The CEDAW Committee has also identified as a central obligation to eliminate discrimination against women the need to address the persistence of gender-based stereotypes impacting women in the law, social structures, institutions, and in the acts of individuals. ${ }^{66}$ How are stereotypes defined? Why are they considered harmful when it comes to women?

${ }^{64}$ For arguments favoring the continued relevance and present need to adopt the Equal Rights Amendment, see Sarah M. Stephens, At the End of Our Article III Rope: Why We Still Need the Equal Rights Amendment, 80 Brook. L. Rev. 407-426 (2015).

${ }_{65}$ For more history on the Equal Rights Amendment and present challenges, see Alex Cohen and Wilfred U. Codrington III, The Equal Rights Amendment Explained, January 23, 2020, www .brennancenter.org/our-work/research-reports/equal-rights-amendment-explained.

66 See CEDAW Committee, General Recommendation 25, Temporary Special Measures, supra note 38 , ๆๆ $6-8$. 
Rebecca Cook and Simone Cusack have defined gender stereotypes as follows:

\begin{abstract}
Stereotyping is part of human nature. It is the way we categorize individuals, often unconsciously into particular groups or types, in part to simplify the world around us. It is the process of ascribing to an individual general attributes, characteristics, or roles by reason only of his or her apparent membership in a particular group. Stereotyping produces generalizations or preconceptions concerning attributes, characteristics, or roles of members of a particular social group, which renders unnecessary consideration of any particular individual member's abilities, needs, wishes, and circumstances.

Stereotypes affect both men and women. However, they often have a particularly egregious effect on women. As one commentator has explained, a "useful way of examining the continued disadvantage of women is to identify the assumptions and stereotypes which have been central to the perpetuation and legitimation of women's legal and social subordination. Such assumptions have roots which stretch deep into the history of ideas, yet continue to influence the legal and social structure of modern society. Indeed, the continuity is startling, given the extent and fundamental nature of change in the political and economic context."

Stereotypes degrade women when they assign them to subservient roles in society, and devalue their attributes and characteristics. Prejudices about women's inferiority and their stereotyped roles generate disrespect and devaluation of women in all sectors of society. ${ }^{67}$
\end{abstract}

Gender-based violence, and its intricate link to discrimination, will be discussed in the following section. The decision below, made by the CEDAW Committee in the case of Karen Vayag Vertido $v$. The Philippines, exemplifies how gender stereotypes can negatively delay the investigation of cases of rape, and what states can do to address this human rights problem.

Karen Tayag Vertido v. Philippines (Excerpts)

Committee on the Elimination of Discrimination against Women

Communication No. 18, 2008, CEDAW/C/46/D/18/2008, July 16, 2010

Citations and footnotes omitted

The author of this complaint is a woman from the Philippines who served as Executive Director of the Davao City Chamber of Commerce and Industry. She claims that the former President of the Chamber raped her on March 29, 1996. Within 48 hours, she reported this crime to the police and filed a complaint with the authorities. The case remained at the trial court level between 1997 and 2005. The Regional Court of Davao City concluded that the testimony of the complainant contained many voids and therefore could not lead to a conviction. The victim alleged before the CEDAW Committee that she was a victim of discrimination against women under Article 1 of CEDAW and that she suffered human rights violations of Articles 2(c), 2(f) and $5(a)$ of the Convention.

8.2 The Committee will consider the author's allegations that gender-based myths and misconceptions about rape and rape victims were relied on by Judge Hofileña Europa in the Regional Court of Davao City in its decision, under article 335 of the Revised Penal Code of 1930, leading to the acquittal of the alleged perpetrator, and will determine whether this amounted to a violation of the rights of the author and a breach of the corresponding State

67 See Rebecca Cook and Simone Cusack, Introduction, in Gender Stereotyping: Transnational Legal Perspectives 1-3 (University of Pennsylvania Press, 2010). 
party's obligations to end discrimination in the legal process under articles 2(c), 2(f) and 5(a) of the Convention. ...

8.4 The Committee further reaffirms that the Convention places obligations on all State organs and that States parties can be responsible for judicial decisions which violate the provisions of the Convention. It notes that by articles 2(f) and 5(a), the State party is obligated to take appropriate measures to modify or abolish not only existing laws and regulations, but also customs and practices that constitute discrimination against women. In this regard, the Committee stresses that stereotyping affects women's right to a fair and just trial and that the judiciary must take caution not to create inflexible standards of what women or girls should be or what they should have done when confronted with a situation of rape based merely on preconceived notions of what defines a rape victim or a victim of gender-based violence, in general. The Committee further recalls its general recommendation No. 19 on violence against women. This general recommendation addresses the question of whether States parties can be held accountable for the conduct of non-State actors. ... States may also be responsible for private acts if they fail to act with due diligence to prevent violations of rights or to investigate and punish acts of violence. ... In the particular case, the compliance of the State party's due diligence obligation to banish gender stereotypes on the grounds of articles 2(f) and 5(a) needs to be assessed in the light of the level of gender sensitivity applied in the judicial handling of the author's case.

8.5 ... The Committee, after a careful examination of the main points that determined the judgement, notes the following issues. First of all, the judgement refers to principles such as that physical resistance is not an element to establish a case of rape, that people react differently under emotional stress, that the failure of the victim to try to escape does not negate the existence of the rape as well as to the fact that "in any case, the law does not impose upon a rape victim the burden of proving resistance". The decision shows, however, that the judge did not apply these principles in evaluating the author's credibility against expectations about how the author should have reacted before, during and after the rape owing to the circumstances and her character and personality. The judgement reveals that the judge came to the conclusion that the author had a contradictory attitude by reacting both with resistance at one time and submission at another time, and saw this as being a problem. ... It is clear from the judgement that the assessment of the credibility of the author's version of events was influenced by a number of stereotypes, the author in this situation not having followed what was expected from a rational and "ideal victim" or what the judge considered to be the rational and ideal response of a woman in a rape situation ... the Committee finds that to expect the author to have resisted in the situation at stake reinforces in a particular manner the myth that women must physically resist the sexual assault. In this regard, the Committee stresses that there should be no assumption in law or in practice that a woman gives her consent because she has not physically resisted the unwanted sexual conduct, regardless of whether the perpetrator threatened to use or used physical violence.

8.6 Further misconceptions are to be found in the decision of the Court, which contains several references to stereotypes about male and female sexuality being more supportive for the credibility of the alleged perpetrator than for the credibility of the victim. ... Other factors taken into account in the judgement, such as the weight given to the fact that the author 
and the accused knew each other, constitute a further example of "gender-based myths and misconceptions."

8.7 With regard to the definition of rape, the Committee notes that the lack of consent is not an essential element of the definition of rape in the Philippines Revised Penal Code. It recalls its general recommendation No. 19 of 29 January 1992 on violence against women, where it made clear, in paragraph 24(b), that "States parties should ensure that laws against family violence and abuse, rape, sexual assault and other gender-based violence give adequate protection to all women, and respect their integrity and dignity". Through its consideration of States parties' reports, the Committee has clarified time and again that rape constitutes a violation of women's right to personal security and bodily integrity, and that its essential element was lack of consent.

8.8 The Committee finally would like to recognize that the author of the communication has suffered moral and social damage and prejudices, in particular by the excessive duration of the trial proceedings and by the revictimization through the stereotypes and gender-based myths relied upon in the judgement. The author has also suffered pecuniary damages due to the loss of her job....

\section{B Reflections and Questions}

1. How are stereotypes connected to discrimination against women? Stereotypes are generalizations about women's potential, capacity, and inclination to perform certain forms of employment, tasks, and roles in a society. They can curb women's opportunities to obtain a comprehensive education at the primary, secondary, and higher education levels, and to enter specific professions that have been male-dominated. Stereotypes about women's role as caretakers have also led to societies built on women's attention to family matters involving children, the elderly, and the sick, as opposed to developing women as leaders and catalysts for change. ${ }^{68}$

2. Can you think of stereotypes that may benefit women? ${ }^{69}$

3. Do men suffer from stereotypes? Historically men have been expected in most societies to be heads of household and the lead income providers for their families. They are also expected to be masculine, strong, and assertive. These are only some examples of the stereotyped notions that men still face socially, which challenge their involvement in the caretaking and raising of their children and in partaking in home responsibilities. There is still stigma associated with men pursuing paternity leave policies and other kinds of leave to care for their children and to negotiate work schedules conducive to helping in the

68 For more reading, see generally Anne Marie Slaughter, Why Women Still Can't Have It All, THE AtlantiC, July/August 2012 issue, www.theatlantic.com/magazine/archive/2012/07/why-women-still -cant-have-it-all/309020/; Marcia L. McCormick, Stereotypes as Channels and the Social Model of Discrimination, 36(1) Saint Louis University Public Law Review, Article 5 (2017), https://papers .ssrn.com/sol3/papers.cfm?abstract_id=3285914.

69 See Lindsay Pattison, How Gender Stereotypes Could Actually Help Women at Work, ForTUNE, May 9, 2017, https://fortune.com/2017/05/09/dealing-with-gender-stereotypes/. 
caretaking of their families. This in turn has affected the possibility of women to work and reach decision-making positions in politics and business, among other sectors. ${ }^{70}$

4. Stereotypes affect women in every realm of social life, including the family, school, employers, the health sector, and in politics. One of the areas in which women have been very negatively impacted by stereotypes is in the investigation, judgment, and sanction of cases related to gender-based violence. In its General Recommendation 33 on access to justice, the CEDAW Committee expressed its concern over stereotyping and gender bias in justice systems, and how these impede the full enjoyment of the rights of women. ${ }^{71}$ The Committee referred in particular to the application by judges of notions of what they consider acceptable behavior for women, and criminalize those who do not conform to these standards. Stereotypes can also affect the credibility offered to women's testimonies and views in these processes, and negatively impact investigations and trials. ${ }^{72}$

5. How do you ensure that the training of justice officials is effective to prevent the application of stereotypes in decision-making? As indicated earlier, one of the most complex problems that women suffer in their quest for justice for acts of discrimination and gender-based violence are forms of revictimization by justice officials, including judges, prosecutors, lawyers, investigators, and law enforcement officials in general. Justice officials can negatively affect the investigation and processing of these cases by applying preconceived notions of how women should behave, dress, and react to specific crimes, including those related to sexual violence. Preconceived notions begin early, in the home, and are later cemented in social tolerance of gender-based violence as normal. Effective training to curb gender-based violence needs to include a process, benchmarks, and forms of accountability. Education at schools, colleges, and law schools of the importance of non-discrimination and the negative influence of stereotypes is also key to eventually producing justice officials which operate free from these notions. ${ }^{73}$

6. Simone Cusack and Alexandra Timmer have referred to the importance of naming stereotypes and identifying them as a social harm, in order to be able to effectively prevent and eradicate them. ${ }^{74}$ They have discussed in their scholarship how Karen Tayag Vertido identified in her complaint a number of stereotypes that harmed her legal process, includ-

70 For more reading see Shelley Zalis, The Future Of Masculinity: Overcoming Stereotypes, FoRBES, January 22, 2019, www.forbes.com/sites/shelleyzalis/2019/01/22/the-future-of-masculinity-overcoming -stereotypes/?sh=361fa9051af3; UN Women, Men Can Transform Gender Stereotypes and Inequality, Speech by UN Women Executive Director Phumzile Mlambo-Ngcuka, November 11, 2014, https://www .unwomen.org/en/news/stories/2014/11/ed-speech-at-menengage-global-symposium-india.

71 See General Recommendation 33 on Women's Access to Justice, Committee on the Elimination of Discrimination against Women, CEDAW/C/GC/33, ๆף 26-29 (July 23, 2015).

72 See id.

73 For more reading, see InTERnAtional COMmisSion of JURISTS, Women's ACCESS TO JUSTICE FOR Gender-Based Violence: A Practitioner's Guide 233-234, 241-242 (International Commission of Jurists, 2016), www.icj.org/wp-content/uploads/2016/03/Universal-Womens-accesss-to-justice -Publications-Practitioners-Guide-Series-2016-ENG.pdf; Inter-American Commission on Human Rights, Access to Justice for Women Victims of Violence in the Americas, OEA/Ser.L/V//II. Doc. 68, qף 182-184 (Jan. 20, 2007), www.cidh.org/women/access07/tocaccess.htm.

74 See Simone Cusack and Alexandra Timmer, Gender Stereotyping in Rape Cases: The CEDAW Committee's Decision in Vertido v The Philippines, 11(2) Human Rights Law Review 7-10 (2011), https://academic.oup.com/hrlr/article-abstract/11/2/329/582590?redirectedFrom=fulltext. 
ing (i) the lack of evidence that a woman physically resisted a sexual assault; (ii) women as untruthful when it comes to allegations of rape; and (iii) older men as not capable of committing rape. Karen Tayag Vertido also identified a number of "rape myths," including the notion that perpetrators of rape are all strangers, and that rape cannot occur between acquaintances. ${ }^{75}$

\section{FINAL COMMENTS: CEDAW IN PRACTICE}

More than forty years have passed since the adoption of CEDAW and there are still many challenges in its implementation. Even though CEDAW has been deeply influential in the reform of constitutions and laws around the world, an adequate legal framework does not guarantee effective enforcement. Political will from states is key to guaranteeing an adequate implementation of CEDAW's dispositions. It is also crucial to disseminate information of CEDAW and state obligations in all sectors of society, and in different languages. One important gain is the active participation of civil society organizations in the work of the CEDAW Committee, and many of the experts in the Committee come from civil society as well.

CEDAW is meant to protect women of different ages, cultures, races, ethnicities, sexual orientations, gender identities, socio-economic standards, and religions. There is important advocacy work devoted to promote the substantive implementation of CEDAW, the lifting of its reservations, the ratification of the Optional Protocol, and compliance with the general recommendations and case decisions adopted by the CEDAW Committee. ${ }^{76}$

75 See id., page 8.

76 For more reading, see Lisa Gormley, 40 Years of Creativity, Striving for Women's Human Rights Across the Globe, London School of Economics, July 12, 2019, https://blogs.lse.ac.uk/wps/2019/07/12/ 40-years-of-creativity-striving-for-womens-human-rights-across-the-globe/; Bandana Rana, Vice-Chair of the CEDAW Committee, Statement Marking 40th Anniversary of CEDAW, December 18, 2019, www.ohchr.org/EN/NewsEvents/Pages/DisplayNews.aspx?NewsID=25443\&LangID=E. 